\title{
Occurrence of antibodies against Neospora caninum and/or Toxoplasma gondii in dogs with neurological signs
}

Ocorrência de anticorpos contra Neospora caninum e/ou Toxoplasma gondii em cães com sinais neurológicos

\section{Nicolle Fridlund Plugge ${ }^{1}$; Fabiano Montiani Ferreira ${ }^{1}$; Rosária Regina Tesoni de Barros Richartz ${ }^{2}$;} Adriana de Siqueira ${ }^{3}$; Rosangela Locatelli Dittrich ${ }^{1 *}$

${ }^{1}$ Programa de Pós-Graduação em Ciências Veterinárias, Universidade Federal do Paraná - UFPR

${ }^{2}$ Centro de Diagnóstico Marcos Enrietti - SEAB/PR

${ }^{3}$ Programa de Patologia Experimental e Comparada, Faculdade de Medicina Veterinária e Zootecnia,

Universidade de São Paulo - USP

Received December 13, 2010

Accepted August 3, 2011

\section{Resumo}

Neste estudo objetivou-se verificar a ocorrência de anticorpos contra Neospora caninum e/ou Toxoplasma gondii em cães com sinais neurológicos. Foram coletadas 147 amostras de sangue, sendo 127 de animais domiciliados (atendidos no Hospital Veterinário da Universidade Federal do Paraná (HV-UFPR) e em clínicas veterinárias da cidade de Curitiba) e 20 de cães errantes da região metropolitana de Curitiba. Os cães apresentavam um ou mais dos seguintes sinais neurológicos: convulsão, paresia ou paralisia, ataxia, alteraçôes de comportamento, alteraçóes sensoriais somáticas e coriorretinite. As amostras foram analisadas pela reação de imunofluorescência indireta (RIFI), na diluição de corte 1:50. Das 147 amostras obtidas, 17 (11,56\%) foram positivas para $N$. caninum, 31 (21,08\%) foram positivas para T. gondii e quatro (2,72\%) foram reagentes para ambos os protozoários. Na titulaçáo dos animais positivos, $54,83 \%$ (17/31) e 41,18\% (07/17) apresentaram títulos $\geq 1: 200$ contra $T$. gondii e $N$. caninum, respectivamente. Diferença significativa $(\mathrm{P}=0,021, \mathrm{OR}=2,87, \mathrm{IC}=1,1>2,8>7,4)$ foi observada para soropositividade ao $T$. gondii entre cães domiciliados $(18,11 \%)$ e errantes $(40 \%)$. Sugere-se a inclusáo dos exames sorológicos de neosporose e toxoplasmose no diagnóstico de doença neurológica em cães.

Palavras-chave: Neospora caninum, Toxoplasma gondii, sorologia, cães, sinais neurológicos.

\begin{abstract}
This study aimed to evaluate occurrences of antibodies against Neospora caninum and Toxoplasma gondii in dogs with neurological signs. Blood samples from 147 dogs were collected: 127 from owned dogs (attended at the Veterinary Teaching Hospital of the Federal University of Paraná (HV-UFPR) and at private veterinary clinics in the city of Curitiba), and 20 from stray dogs found in Curitiba's metropolitan region. The dogs presented one or more of the following neurological signs: seizures, paresis or paralysis, ataxia, behavioral abnormalities, sensory and somatic disorders and chorioretinitis. The samples were analyzed by means of the indirect fluorescent antibody test (IFAT), at a cutoff dilution of 1:50. Out of the 147 samples obtained, 17 (11.56\%) were seropositive for $N$. caninum, $31(21.08 \%)$ for $T$. gondii and four $(2.72 \%)$ for both protozoa. Serum titration on the positive animals showed that 54.83\% (17/31) and 41.18\% (7/17) had titers $\geq 1: 200$ against T. gondii and $N$. caninum, respectively. A significant difference in seropositivity for $T$. gondii $(\mathrm{P}=0.021$; $\mathrm{OR}=2.87$; $\mathrm{CI}=1.1>2.8>7.4$ ) was observed between owned dogs $(18.11 \%)$ and stray dogs $(40 \%)$. Inclusion of serological tests for neosporosis and toxoplasmosis is recommended in diagnosing neurological diseases in dogs.
\end{abstract}

Keywords: Neospora caninum, Toxoplasma gondii, serology, dogs, neurological signs.

\footnotetext{
${ }^{*}$ Corresponding author: Rosangela Locatelli Dittrich

Programa de Pós-Graduaçáo em Ciências Veterinárias,

Universidade Federal do Paraná - UFPR, Rua dos Funcionários, 1540,

CEP 80035-050, Curitiba - PR, Brasil;

e-mail: roslocdi@ufpr.br
} 


\section{Introduction}

Neospora caninum and Toxoplasma gondii are protozoan parasites with worldwide distribution that cause neuromuscular disease in many animals, including dogs (PARADIES et al., 2007). Neospora caninum is capable of infecting various species of domestic and wild animals, and it is considered to be the main cause of abortions among cattle (RIVERA, 2001; DUBEY et al., 2007). Dogs are the definitive hosts of $N$. caninum and are important in the transmission cycle to other animals. In dogs, neosporosis causes neuromuscular, heart, lung and skin diseases (DUBEY, 2003; McINNES et al., 2006).

Few serological-epidemiological studies on neosporosis in dogs presenting neurological signs have been conducted (YILDIZ et al., 2009). In dogs without neurological signs, several studies have demonstrated that the seroprevalence of antibodies against $N$. caninum ranges from 1 to $20 \%$, and it may be up to $100 \%$ in endemic areas (ANTONY; WILLIAMSON, 2003; DUBEY et al., 2007). In Brazil, the seroprevalence ranges from 4 to $54.2 \%$, also in dogs without neurological signs (ROMANELLI et al., 2007; FIGUEREDO et al., 2008).

Neurological diseases caused by protozoa are little diagnosed in dogs, and most such cases are attributed to T. gondii. Toxoplasmosis in dogs is difficult to diagnose because of its chronic nature, which results from the high infectivity and low pathogenicity of the parasite. Clinical toxoplasmosis may be associated with the canine distemper virus or other immunosuppressive conditions that predispose towards multiplication of the protozoon (DUBEY et al., 2003; MORETTI et al., 2006).

The seroprevalence of T. gondii in dogs without neurological signs is high in Brazil, with rates ranging from 21 to $91 \%$ (SOUZA et al., 2003; ORTOLANI et al., 2005; FIGUEREDO et al., 2008). Most studies on the prevalence of $N$. caninum and $T$. gondii have been conducted on healthy dogs, and the information on disease occurrence in animals with neurological signs remains limited. Within this context, the aims of this study were to determine the prevalence of antibodies against $N$. caninum and $T$. gondii in dogs with neurological signs.

\section{Material and Methods}

Between March 2006 and March 2007, 147 blood samples were collected from dogs with neurological signs, in order to obtain serum. This project was approved by the Ethics Committee of the Federal University of Paraná (UFPR) (Protocol N 033/2006). The samples were obtained from owned animals that were attended routinely at the Veterinary Hospital of UFPR (HV-UFPR) and at veterinary clinics located in Curitiba (127 dogs); and from stray animals found within the city's metropolitan region, which had been brought into the Zoonosis Control Centers of the municipalities of Pinhais (seven dogs) and São José dos Pinhais (eight dogs) and the non-governmental organization Association of Animal Friends in Campo Magro (five dogs). After neurological and ophthalmic examinations, the clinical files from the neurological examinations on animals with one or more neurological signs were identified and divided according to category of clinical sign.
The classical definitions were used to categorize the neurological signs encountered: seizures, paresis or paralysis, ataxia, behavioral abnormalities, sensory and somatic disorders and chorioretinitis.

The indirect fluorescent antibody test (IFAT), was used to detect antibodies against $N$. caninum and T. gondii in the animals' serum. Slides were prepared, containing tachyzoites of $N$. caninum (strain NC-1) and T. gondii (strain RH), obtained through cell culturing as described by Locatelli-Dittrich et al. (2006). The serum samples were tested at an initial dilution of 1:50, in PBS solution ( $\mathrm{pH} 7.2$ ) and were analyzed in pairs until reaching to the final titer. Conjugated anti-dog IgG was used (SigmaÒ).

The test used for the statistical analysis on proportions between the number of positive samples and the total number of samples studied in the diferent groups was Fisher's exact test $(\mathrm{P} \leq 0.05)$.

\section{Results}

Out of the 147 samples, $52(35.37 \%)$ were positive for $N$. caninum and/or T. gondii: 17 (11.56\%) for $N$. caninum, $31(21.08 \%)$ for T. gondii and four (2.72\%) for both. Out of the 127 samples collected from owned animals, 14 (11.02\%) were reactive to $N$. caninum, $23(18.11 \%)$ to $T$. gondii and two $(1.57 \%)$ to $N$. caninum and T. gondii. Out of the eight samples collected from stray dogs at the Zoonosis Control Center in São José dos Pinhais, one $\operatorname{dog}(12.50 \%)$ was seropositive for $T$. gondii and one (12.50\%) for both protozoa. The seven samples obtained from stray dogs at the Zoonosis Control Center in Pinhais were all positive: three (42.86\%) for $N$. caninum, three (42.86\%) for $T$. gondii and one (14.28\%) for $N$. caninum and $T$. gondii. Out of the five samples obtained from the Association of Animal Friends, four (80\%) were positive for $T$. gondii and none for $N$. caninum. A significant difference $(\mathrm{P}=0.0014 ; \mathrm{OR}=5.75 ; \mathrm{CI}=1.7>5.7>18.5)$ was observed between the samples collected from dogs at HV-UFPR and from dogs at the non-governmental organization Association of Animal Friends, in relation to the presence of antibodies against T. gondii. There was no significant difference $(\mathrm{P}>0.05)$ among the other groups analyzed (Table 1).

Through comparing the animals according to their origin, the owned dogs presented occurrence rates of $11.02 \%(14 / 127)$ and $18.11 \%(23 / 127)$ for antibodies against $N$. caninum and T. gondii, respectively. Among the stray dogs, the occurrence rates were $15.00 \%(3 / 20)$ for $N$. caninum and $40 \%(8 / 20)$ for T. gondii. The seropositivity found for the two protozoa together was $1.57 \%$ among the owned dogs and $10.00 \%$ among the stray dogs (Table 2). There was a significant difference between the owned and stray dogs regarding the presence of antibodies against T. gondii $(\mathrm{P}=0.021 ; \mathrm{OR}=2.87 ; \mathrm{CI}=1.1>2.8>7.4)$. There was no significant difference in seropositivity for $N$. caninum or for both protozoa, comparing dogs from different origins $(\mathrm{P}>0.05)$.

The titers of the $17 \mathrm{dogs}$ that were seropositive for $N$. caninum were: $1: 50$ (47.06\%; 8/17); 1:100 (11.76\%; 2/17); 1:200 (23.53\%; $4 / 17)$; and $1: 800(17.65 \% ; 3 / 17)$. The titers of the 31 dogs that were seropositive for T. gondii were: $1: 50(25.80 \% ; 8 / 31) ; 1: 100$ (19.35\%; 6/31); 1:200 (32.26\%; 10/31); 1:400 (6.45\%; 2/31); and $1: 800(16.13 \% ; 5 / 31)$. Out of the four dogs that were seropositive 
Table 1. Occurrences of antibodies against Neospora caninum and/or Toxoplasma gondii (IFAT $\geq 50$ ) among dogs with neurological signs in Curitiba and its metropolitan region, Paraná, Brazil.

\begin{tabular}{|c|c|c|c|c|c|c|c|}
\hline \multirow{3}{*}{ Region } & \multirow{3}{*}{$\begin{array}{c}\text { Dogs } \\
\mathrm{n}\end{array}$} & \multicolumn{6}{|c|}{ Seropositivity } \\
\hline & & \multicolumn{2}{|c|}{ N. caninum } & \multicolumn{2}{|c|}{ T. gondii } & \multicolumn{2}{|c|}{$N$. caninum and $T$. gondi } \\
\hline & & $\mathbf{n}$ & $\%$ & $\mathbf{n}$ & $\%$ & $\mathbf{n}$ & $\%$ \\
\hline HV-UFPR/Clinics & 127 & 14 & 11.02 & $23^{a}$ & 18.11 & 02 & 1.57 \\
\hline ZCC São José dos Pinhais & 08 & 00 & 00 & $01^{\mathrm{ab}}$ & 12.50 & 01 & 12.50 \\
\hline ZCC Pinhais & 07 & 03 & 42.86 & $03^{\mathrm{ab}}$ & 42.86 & 01 & 14.28 \\
\hline NGO Animal Friends & 05 & 00 & 00 & $04^{\mathrm{b}}$ & 80.00 & 00 & 00 \\
\hline Total & 147 & 17 & 11.56 & 31 & 21.08 & 04 & 2.72 \\
\hline
\end{tabular}

Different letters in the column $=\mathrm{P} \leq 0.05 ; \mathrm{ZCC}=$ Zoonosis Control Center; HV/UFPR = Veterinary Hospital of the Federal University of Paraná; Ngo = non-governmental organization.

Table 2. Occurrences of antibodies against Neospora caninum and Toxoplasma gondii (IFAT $\geq 50$ ) among owned and stray dogs with neurological signs in Curitiba and its metropolitan region, Paraná, Brazil.

\begin{tabular}{|c|c|c|c|c|c|c|c|}
\hline \multirow[t]{3}{*}{ Origin } & \multirow{3}{*}{$\begin{array}{c}\text { Dogs } \\
\mathrm{n} \\
\end{array}$} & \multicolumn{6}{|c|}{ Seropositivity } \\
\hline & & \multicolumn{2}{|c|}{ N. caninum } & \multicolumn{2}{|c|}{ T. gondii } & \multicolumn{2}{|c|}{$\begin{array}{l}N . \text { caninum } \\
\text { and T. gondit }\end{array}$} \\
\hline & & $\mathrm{n}$ & $\%$ & $\mathbf{n}$ & $\%$ & $\mathbf{n}$ & $\%$ \\
\hline Owned & 127 & 14 & 11.02 & 23 & $18.11^{\mathrm{a}}$ & 02 & 1.57 \\
\hline Stray & 20 & 03 & 15.00 & 08 & $40.00^{\mathrm{b}}$ & 02 & 10.00 \\
\hline Total & 147 & 17 & 11.56 & 31 & 21.08 & 04 & 2.72 \\
\hline
\end{tabular}

Different letters in the column $=\mathrm{P} \leq 0.05$.

for both parasites, three presented titers of 1:50 (75\%) and one presented a titer of 1:200 (25\%).

The neurological abnormalities observed were seizures, paresis or paralysis of the forelimbs and/or hind limbs, ataxia, behavioral changes, sensory abnormalities (such as loss of nociception or proprioception) and chorioretinitis. The dogs were of various ages, both sexes and different breeds, and no trends were revealed in relation to any of these traits.

\section{Discussion}

Most of the reports on the seroprevalence of $N$. caninum and T. gondii, both in Brazil and in several other countries, have been obtained from asymptomatic dogs. There have been variations in the rates between diferent Brazilian States (GARCIA et al., 1999; AZEVEDO et al., 2005).

There are only a few reports on the seroprevalence of neosporosis and toxoplasmosis among dogs with neurological signs (VARANDAS et al., 2001; GIRALDI et al., 2002; YILDIZ et al., 2009). In the present study, occurrences of antibodies in dogs with neurological signs were greater for $T$. gondii $(21.08 \%)$ than for $N$. caninum (11.56\%), or for both parasites together $(2.72 \%)$. Results like these were previously described by Mineo et al. (2001), Giraldi et al. (2002), Varandas et al. (2001) and Klein and Müller (2001), among others. In Minas Gerais, the seroprevalences were 3.3, 3.7 and 3.1\%, respectively, for T. gondii, N. caninum and both parasites together, in dogs with neurological, respiratory and/or gastrointestinal diseases (MINEO et al., 2001). In the
Northeastern region of the State of São Paulo, the seroprevalences were, respectively, 8.14, 1.36 and $5.76 \%$, for $T$. gondii, $N$. caninum and both of them together, without any correlation between positive serological tests and the presence of neuropathies in the animals (VARANDAS et al., 2001). In Londrina, the seroprevalence of toxoplasmosis was high (35.4 to $77.6 \%)$ and neosporosis was not diagnosed (GIRALDI et al., 2002). In Germany, the seroprevalence among dogs with signs was also greater for T. gondii $(29 \%$ and titer $\geq 1: 32$ ) than for $N$. caninum $(13 \%$ and titer $\geq 1: 50)$ (KLEIN; MÜLLER, 2001).

The occurrences of antibodies against T. gondii and N. caninum among the stray dogs in the present study were 40 and $15 \%$, respectively. In the owned dogs, antibodies against $T$. gondii and $N$. caninum were observed in 18.11 and $11.02 \%$ of the dogs, respectively. Comparing the owned and stray dogs, there was a significant difference in relation to the presence of antibodies against T. gondii $(\mathrm{P}=0.021 ; \mathrm{OR}=2.87 ; \mathrm{CI}=1.1>2.8>7.4)$, thus demonstrating that access to the streets may be a risk factor for infection and may contribute towards greater seropositivity of $T$. gondii. This result has also been observed among stray dogs in other regions (BARBOSA et al., 2003; MOURA et al., 2009).

For $N$. caninum and for both protozoa together, there was no significant difference between the owned and stray dogs regarding antibody occurrences. This result was similar to the findings from other studies conducted in Bahia and Paraná, which also did not find differences between owned and stray dogs (JESUS et al., 2006; FRIDLUND-PLUGGE et al., 2008). However, there have been reports of lower seroprevalence of $N$. caninum among owned dogs (AZEVEDO et al., 2005) and greater chances of infection among street dogs (GENNARI et al., 2002).

The main neurological signs observed in the dogs that were reactive to $N$. caninum were paresis/paralysis, seizures and ataxia. In the dogs that were seropositive for $T$. gondii, the main signs were also seizures, ataxia and paralysis. However, in Londrina, Paraná, myoclonus was the sign most frequently presented by the dogs that were seropositive for $T$. gondii (GIRALDI et al., 2002). In the present study, the clinical signs were similar for the two diseases, but there were greater occurrences of $T$. gondii, thus corroborating some other results observed previously (MINEO et al., 2001; VARANDAS et al., 2001; GIRALDI et al., 2002).

In the present study, the titers of the dogs that were positive for $N$. caninum ranged from 1:50 to 1:800, with predominance 
of the titers 1:50 and 1:200. The titers reported for dogs with clinical neosporosis, measured using IFAT, have been 1:50 and 1:3200 (DUBEY et al., 1998; KLEIN; MÜLLER, 2001), although IgG titers are generally greater than 1:400 (DUBEY et al., 1998; BASSO et al., 2005).

Antibodies against $N$. caninum have also been observed in dogs without neurological signs. Hence, simply the presence of antibodies does not indicate clinical neosporosis (AZEVEDO et al., 2005; VÁCLAVEK et al., 2007; FRIDLUND-PLUGGE et al., 2008). On the other hand, in cases of seronegative dogs or dogs with small titers, neosporosis should not be ruled out. Serological tests should be used to make the clinical diagnosis, but the titers remain undefined and vary according to the serological test. Progressive increases in the antibody titers of class $\mathrm{IgG}$ over a period of time are generally indicative of acute infection (DUBEY et al., 1998).

The titers for T. gondii presented by the dogs ranged from $1: 50$ to $1: 800$, with predominance of $1: 50$ and $1: 200$. Other authors have taken into account titers of 1:16 (GIRALDI et al., 2002) or 1:32 (KLEIN; MÜLLER, 2001), but the occurrences observed in the present study may have been greater because of the cutoff point used (1:50). Given that $32.26 \%$ of the dogs that were seropositive for T. gondii presented high titers (1:200), toxoplasmosis may have been the cause of the neuropathy cases observed.

Serological tests to identify infection by $N$. caninum and T. gondii should be done in cases of dogs with neuromuscular signs, even if canine distemper is suspected, because of the similarity of the clinical signs (TARLOW et al., 2005; MORETTI et al., 2006). Most of the stray dogs in the municipality of Pinhais were sent to the Zoonosis Control Center with suspected canine distemper because of the presence of neurological signs, but then the serological tests showed high titers for T. gondii (42.86\%) and N. caninum (42.86\%).

Detection of serum antibody titers against $N$. caninum or T. gondii in animals with neurological signs obviously does not necessarily establish a cause-effect relationship. Nevertheless, the prevalence of animals with neurological signs and positive findings for one or both of the protozoa was high in the present study. Knowledge of this prevalence, along with descriptions of the neurological signs most commonly observed in these animals, is extremely important for understanding both of these diseases. Neosporosis should certainly be included in the differential diagnosis of neurological diseases like chorioretinitis, canine distemper and rabies, but in Brazil, toxoplasmosis is still the main parasitic disease investigated in the differential diagnosis of neurological diseases. In the present study, just as in Minas Gerais (MINEO et al., 2001), it was observed that the serological test to identify infection by $N$. caninum in dogs that show neuromuscular signs should be included in the differential diagnosis for infection by T. gondii.

\section{Conclusion}

It was found that a significant percentage of the dogs with neurological signs were infected with the protozoa $N$. caninum (11.56\%), T. gondii (21.08\%) or both (2.72\%). Seropositivity for the two diseases was widely distributed among the population studied. This result suggests that clinical veterinarians should be more attentive in drawing up differential diagnoses. Serological tests for toxoplasmosis and/or neosporosis should be requested in the cases of dogs with neurological abnormalities, even if canine distemper or another disease of the central nervous system is suspected, because of the similarity of the clinical signs observed and the possibility of coinfection in the animals.

\section{Acknowledgements}

To CNPq for the Master's bursary granted; to the Araucária Foundation and to the Federal University of Paraná for their financial support. To the Veterinary Hospital of the Federal University of Paraná (HV-UFPR), Clinivet Veterinary Diagnostic Center and Hospital, Clinicão Veterinary Clinic, the Zoonosis Control Centers of Pinhais and São José dos Pinhais and the non-governmental organization Association of Animal Friends, for making samples available.

\section{References}

ANTONY, A.; WILLIAMSON, N. B. Prevalence of antibodies to Neospora caninum in dogs of rural or urban origin in central New Zealand. New Zealand Veterinary Journal, v. 51, n. 5, p. 232-237, 2003. PMid:16032332. http://dx.doi.org/10.1080/00480169.2003.36372

AZEVEDO, S. S. et al. Seroepidemiology of Toxoplasma gondii and Neospora caninum in dogs from the State of Paraíba, Northeast region of Brazil. Research in Veterinary Science, v. 79, n. 1, p. 51-56, 2005. PMid:15894024. http://dx.doi.org/10.1016/j.rvsc.2004.10.001

BARBOSA, M. V. F. et al. Freqüência de anticorpos IgG anti-Toxoplasma gondii em soros de cães errantes da cidade de Salvador-Bahia, Brasil. Brazilian Journal of Veterinary Research and Animal Science, v. 40, n. 6, p. 457-465, 2003. http://dx.doi.org/10.1590/S141395962003000600010

BASSO, W. et al. Confirmed clinical Neospora caninum infection in a boxer puppy from Argentina. Veterinary Parasitology, v. 131, n. 3-4, p. 299-303, 2005. PMid:15978728. http://dx.doi.org/10.1016/j. vetpar.2005.05.003

DUBEY, J. P. et al. Canine neosporosis: clinical signs, diagnosis, treatment and isolation of Neospora caninumin mice and cell culture. International Journal for Parasitology, v. 28, n. 8, p. 1293-1304, 1998. http://dx.doi. org/10.1016/S0020-7519(98)00099-X

DUBEY, J. P. Review of Neospora caninum and neosporosis in animals. The Korean Journal Parasitology, v. 41, n. 1, p. 1-16, 2003. http://dx.doi.org/10.3347/kjp.2003.41.1.1

DUBEY, J. P.; ROSS, A. D.; FRITZ, D. Clinical Toxoplasma gondii, Hammondia heydorni and Sarcocystis spp. infections in dogs. Parassitologia,v. 45, n. 3-4, p. 141-146, 2003. PMid:15267102.

DUBEY, J. P.; SCHARES, G.; ORTEGA-MORA, L. M. Epidemiology and control of Neosporosis and Neospora caninum.Clinical Microbiology Reviews, v. 20, n. 2, p. 323-367, 2007.PMid:17428888. PMCid:1865591. http://dx.doi.org/10.1128/CMR.00031-06

FIGUEREDO, L. A. et al. Occurrence of antibodies to Neospora caninum and Toxoplasma gondii in dogs from Pernambuco, Northeast Brazil. 
Veterinary Parasitology, v. 157, n. 1-2, p. 9-13,2008. PMid:18723288. http://dx.doi.org/10.1016/j.vetpar.2008.07.009

FRIDLUND-PLUGGE, N. et al. Frequency of antibodies against Neospora caninum in stray and domiciled dogs from urban, periurban and rural areas from Paraná State, Southern Brazil. Revista Brasileira de Parasitologia Veterinária, v. 17, n. 4, p. 222-226, 2008.

GARCIA, J. L. et al. Soroepidemiologia da toxoplasmose em gatos e cães de propriedades rurais do município de Jaguapitã, Estado do Paraná, Brasil. Ciência Rural, v. 29, n. 1, p. 99-104, 1999.

GENNARI, S. M. et al. Occurence of Neospora caninum antibodies in sera from dogs of the city of São Paulo, Brasil. Veterinary Parasitology, v. 106, n. 2, p. 177-179, 2002. http://dx.doi.org/10.1016/S03044017(02)00052-3

GIRALDI, J. H. et al. Sorologia e histopatologia de Toxoplasma gondii e Neospora caninum em cães portadores de distúrbios neurológicos. Semina: Ciências Agrárias, v. 23, n. 1, p. 9-14, 2002.

JESUS, E. E. V. et al. Freqüência de anticorpos anti-Neospora caninum em cáes nos municípios de Salvador e Lauro de Freitas, Estado da Bahia - Brasil. Brazilian Journal of Veterinary Research and Animal Science, v. 43 , n. 1 , p. $5-10,2006$

KLEIN, B. U.; MÜLLER, E. Seroprävalenz von Antikörpern gegen Neospora caninum bei Hunden mit und ohne klinischen Neosporoseverdacht in Deutschland. Praktischer Tierärzt, v. 82, n. 6, p. 437-440, 2001

LOCATELLI-DITTRICH, R. et al. Investigation of Neospora sp. and Toxoplasma gondii antibodies in mares and in precolostral foals from Parana State, Southern Brazil. Veterinary Parasitology,v. 135, n. 3-4, p. 215-221, 2006. PMid:16289863. http://dx.doi.org/10.1016/j. vetpar.2005.10.010

McINNES, L. M. et al. In vitro isolation and characterization of the first canine Neospora caninum isolate in Australia. Veterinary Parasitology, v. 137, n. 3-4, p. 355-363, 2006. PMid:16487658. http://dx.doi. org/10.1016/j.vetpar.2006.01.018

MINEO, T. W. P. et al. Detection of IgG antibodies to Neospora caninum e Toxoplasma gondii in dogs examined in a veterinary hospital from Brazil. Veterinary Parasitology, v. 98, n. 4, p. 239-245, 2001. http://dx.doi. org/10.1016/S0304-4017(01)00441-1
MORETTI, L. et al. Toxoplasma gondii genotyping in a dog co-infected with distemper virus and ehrlichiosis rickettsia. Revista do Instituto de Medicina Tropical de Sáo Paulo,v. 48, n. 6, p. 359-363, 2006.

MOURA, A. B et al. Ocorrência de anticorpos e fatores de risco para infecção por Toxoplasma gondii em cães, nas cidades de Lages e Balneário Camboriú, Santa Catarina, Brasil. Revista Brasileira de Parasitologia Veterinária, v. 18, n. 3, p. 52-56, 2009.

ORTOLANI, E. S. et al. Prevalência de anticorpos anti-Toxoplasma gondii em populaçóes animais das aldeias indígenas Krucutu e Morro da Saudade, no município de São Paulo, Brasil. Veterinária e Zootecnia, v. 12 , n. $1-2$, p. $25-28,2005$.

PARADIES, P. et al. Risk factors for canine neosporosis in farm and kennel dogs in southern Italy. Veterinary Parasitology, v. 145, n. 3-4, p. 240-244, 2007. PMid:17257762. http://dx.doi.org/10.1016/j. vetpar.2006.12.013

RIVERA, G. H. Causas frecuentes de aborto bovino. Revista de Investigaciones Veterinarias del Perú,v. 12, n. 2, p. 117-122, 2001.

ROMANELLI, P. R. et al. Prevalence of Neospora caninum and Toxoplasma gondii in sheep and dogs from Guarapuava farms, Paraná State, Brazil. Research in Veterinary Science,v. 82, n. 2, p. 202-207, 2007. PMid:17266999. http://dx.doi.org/10.1016/j.rvsc.2006.04.001

SOUZA, S. L. P. et al. Occurence of Toxoplasma gondii antibodies in sera from dogs of the urban and rural areas from Brazil. Revista Brasileira de Parasitologia Veterinária,v. 12, n. 1, p. 1-3, 2003.

TARLOW, J. M. et al. Emergency presentations of 4 dogs with suspected neurologic toxoplasmosis. Journal of Veterinary Emergency and Critical Care, v. 15, n. 2, p. 119-127, 2005. http://dx.doi.org/10.1111/ j.1476-4431.2005.00134.x

VÁCLAVEK, P. et al. Serological survey of Neospora caninum in dogs in the Czech Republic and a long-term study of dynamics of antibodies. Veterinary Parasitology, v. 143, n. 1, p. 35-41,2007.

VARANDAS, N. P. et al. Freqüência de anticorpos anti-Neospora caninum e anti- Toxoplasma gondii em cães da região nordeste do Estado de São Paulo. Correlação com neuropatias. Semina: Ciências Agrárias, v. 22, n. 1, p. 105-111, 2001.

YILDIZ, K. et al. Seroprevalence of Neospora caninum and coexistence with Toxoplasma gondii in dogs. Türkiy e Parazitoloji Dergisi, v. 33, n. 2, p. 116-119, 2009. 